\title{
An Inorganic Mercury Hazard in the Manufacture of Artificial Jewellery
}

\author{
J. F. COPPLESTONE and D. A. McARTHUR \\ From the Occupational Health Unit, Department of Health, Wellington, New Zealand
}

An unusual inorganic mercury hazard in a factory manufacturing artificial jewellery is described. Considerable exposure of workers was confirmed by levels of up to $2,000 \mu \mathrm{g}$. $/ 1$. of mercury in urine. The air concentration was also found to be correspondingly high, up to $0.5 \mathrm{mg} . / \mathrm{m} .{ }^{3}$ of mercury in the general atmosphere. Preventive measures have resulted in a slow fall in urinary concentrations over a period of several months. Despite the high results obtained, no worker showed any overt evidence of mercurialism. The significance of this is considered in the discussion and it is suggested that mercurialism may be due to a failure in excretion. If this is so, it would have a considerable effect on surveillance techniques; furthermore such a hypothesis may account for the anomalies that are well known in the surveillance of workers exposed to mercury.

The difficulties of the surveillance, by biological methods, of workers exposed to inorganic mercury vapour are well known and have been extensively reviewed by Goldwater, Jacobs, and Ladd (1962, 1963), Goldwater and Nicolau (1966), Ladd, Goldwater, and Jacobs (1963), and Jacobs, Ladd, and Goldwater (1963, 1964) in a comprehensive series of papers. The most convenient and practicable method is the estimation of urinary mercury and, although this may confirm exposure and is valid on a group basis, the test cannot at present be reliably used for predicting the onset of merturialism in a worker if exposure is continued.

This paper outlines investigations which were carried out in a factory manufacturing jewellery. It illustrates that the hazard can occur in unexpected places, and that high levels of urinary mercury appear to be compatible in some individuals with apparently normal health.

\section{The Process}

The jewellery is manufactured by a process similar to the 'lost wax' method except that, instead of wax, a mercury cadmium amalgam is used. The process is carried out in three basement rooms. In the mould room, the heated amalgam is poured into rubber moulds which are then rotated in an uncovered centrifuge to ensure complete filling of the mould. After removal of the rubber casing, the

Received for publication June 13, 1966. castings are taken to the plaster casting room where they are encased. From here they pass to the oven room where the plaster casts are heated to $1,000-$ $1,200^{\circ} \mathrm{C}$. in ovens overnight. The amalgam runs out of the plaster mould and is recovered. Finally, the plaster mould is filled with gold or various alloys of precious and grosser metals. A closed still for recovery purposes is also situated in the oven room.

The factory first came to the notice of the Occupational Health Unit early in 1965 through the Department of Labour who were concerned about the theoretical risk in association with rather poor housekeeping. This was largely corrected before investigations began. There had been no complaints of illness among the employees, most of whom had worked at the factory since it opened three years previously.

\section{Investigations}

It was decided that a significant mercury hazard was likely to be present at the following sites in the factory:

(I) Mould room: Two melting pots for amalgam, under hoods; unventilated centrifuges; wall storage racks for rubber moulds

(2) Plaster casting room: Small quantities of mercury-containing dust

(3) Oven room: Two electric ovens plus a mercury still for the melting of amalgam; floor sweepings kept in covered rubbish cans in this room. 
The first stage of the investigation was to carry out urinary mercury estimations. It was found impracticable to collect 24 -hour specimens and, after tests on the first series of specimens had been completed, early morning urine specimens were analysed at monthly intervals from the four members of the staff who were working at points considered to be hazardous. To avoid possible contamination of the urine it was arranged that specimens should be passed at home. The manager and foreman were included as controls; the former rarely entered this section of the factory, and the latter worked with mercury only occasionally. Urine specimens were preserved by the addition to the specimen bottle of a small amount of toluene to avoid bacterial volatilization of mercury (Magos, Tuffery, and Clarkson, 1964). Only specimens with a specific gravity greater than Ioro were accepted.

Urine mercury analysis consisted of acid permanganate digestion of the specimen under reflux for six hours, decolourization with hydroxylamine hydrochloride, extraction with a carbon tetrachloride solution of dithizone at $\mathrm{pH} 0.8$, and spectrophotometric determination of mercury dithizonate in the presence of excess dithizone. Standards included in each batch of analyses were used for calibration. Investigation of potential interference by copper, silver, and gold under these conditions has shown that, even when the ions of these metals are present in concentrations ro times greater than those of mercury, no significant interference is given by copper or gold. Although the interference by silver is detectable (ro $\mu \mathrm{g}$. silver gave an absorbance equivalent to that given by $3.2 \mu \mathrm{g}$. mercury), workers $A$ and $B$ were not associated with the final casting process and hence were exposed to cadmium- mercury alone. The other workers under surveillance were exposed regularly to cadmium and mercury, and, intermittently, to silver. Interference by tin, zinc, and cadmium was avoided by extraction at the strongly acid $\mathrm{pH}$.

The concentrations, as $\mu \mathrm{g}$. mercury/litre of urine, were adjusted to a mean specific gravity of $\mathrm{I} \cdot 024$ by multiplying the actual mercury concentration by $24 / G$, where $G$ represents the last two figures of the specific gravity of the original sample (e.g., $G=$ $\mathrm{I} \cdot 018-\mathrm{I} \cdot 000=\mathrm{I} 8$ ).

The results of these tests are shown in Table I.

The manager was found to have normal levels in the urine and the foreman had only slightly raised levels. Workers $A$ and $B$, both women and aged 57 and 40 respectively, work in the mould room. They showed high levels of mercury excretion, the highest values being $1,750 \mu \mathrm{g}$. $/ 1$. for worker $A$ and 2,000 $\mu \mathrm{g}$./1. for worker B. Over the Io months of surveillance, the level of $\mathrm{I}, 000 \mu \mathrm{g}$./1. was exceeded by worker $A$ on two occasions and by worker $B$ on six occasions.

Workers $\mathrm{C}$ and $\mathrm{D}$, both male and aged 20 and $\mathrm{I} 7$ respectively, work in the oven room. Both showed raised levels but not to the same extent as workers A and B. However, worker D achieved the highest result recorded, 2,090 $\mu \mathrm{g}$./1., after cleaning out a flue containing sublimated mercury. He worked on this occasion with worker C but they had only one respirator between them. It is apparent that the respirator was allotted according to seniority. Worker C left the firm in November 1965 for reasons unconnected with his exposure.

The results for January and February 1966 show considerable reductions in urinary mercury levels. This is probably due to two factors: the factory was

TABLE I

URINe Mercury Concentrations ( $\mu \mathrm{g}$./1.)

\begin{tabular}{|c|c|c|c|c|c|c|c|c|}
\hline & & & \multirow{2}{*}{ Manager } & \multirow{2}{*}{ Foreman } & \multicolumn{4}{|c|}{ Employees } \\
\hline & & & & & $A(F$. aged 57) & $B(F$. aged 40$)$ & $C$ (M. aged 20) & $D$ (M. aged 17) \\
\hline $\begin{array}{l}1965 \\
\text { April } \\
\text { May.. } \\
\text { June.. } \\
\text { July .. } \\
\text { August } \\
\text { September } \\
\text { October } \\
\text { November } \\
\text { I966 } \\
\text { January } \\
\text { February }\end{array}$ & $\begin{array}{l}\ldots \\
\ldots \\
\ldots \\
\ldots \\
\ldots \\
\ldots \\
\ldots \\
\\
\ldots \\
\ldots\end{array}$ & $\begin{array}{l}. \\
\cdots \\
\cdots \\
\cdots \\
\cdots \\
\cdots \\
\cdots\end{array}$ & $\begin{array}{l}<50 \\
<50 \\
<50\end{array}$ & $\begin{array}{r}200 \\
110 \\
<50 \\
<50 \\
<50 \\
110 \\
80 \\
60\end{array}$ & $\begin{array}{r}1,000 \\
780 \\
850 \\
200 \\
440 \\
880 \\
790 \\
1,750\end{array}$ & $\begin{array}{r}1,380 \\
1,170 \\
1,010 \\
480 \\
1,690 \\
870 \\
>2,000 \\
1,650 \\
\\
630 \\
340\end{array}$ & $\begin{array}{l}260 \\
700 \\
720 \\
670 \\
830 \\
890 \\
610 \\
\text { Left }\end{array}$ & $\begin{array}{r}170 \\
2,090 \\
990 \\
500 \\
730 \\
960 \\
900 \\
580\end{array}$ \\
\hline
\end{tabular}


TABLE II

MERCURY IN AIR (mg./m. $\left.{ }^{3}\right)$

\begin{tabular}{|c|c|c|c|c|c|c|}
\hline & \multicolumn{2}{|c|}{ Mould Room } & \multirow{2}{*}{$\begin{array}{l}\text { Oven } \\
\text { Room }\end{array}$} & \multirow{2}{*}{$\begin{array}{l}\text { Plaster } \\
\text { Casting } \\
\text { Room }\end{array}$} & \multirow{2}{*}{$\begin{array}{l}\text { Entrance } \\
\text { Room }\end{array}$} & \\
\hline & $\begin{array}{l}\text { General } \\
\text { Air }\end{array}$ & $\begin{array}{c}\text { Above } \\
\text { Centrifuge }\end{array}$ & & & & \\
\hline $\begin{array}{l}\text { I965 } \\
\text { July }\end{array}$ & 0.5 & 0.6 & $\begin{array}{c}\text { O.I } \\
\text { (o.9 while still } \\
\text { being emptied) }\end{array}$ & & 0.04 & $\begin{array}{l}\text { Average levels over } \\
\text { sampling period }\end{array}$ \\
\hline $\begin{array}{l}\text { November } \\
\text { December }\end{array}$ & $\begin{array}{c}0 \cdot 35 \\
0 \cdot 1-0 \cdot 2\end{array}$ & $\begin{array}{l}0 \cdot 8-\mathrm{I} \cdot 2 \\
0 \cdot 3-0 \cdot 5\end{array}$ & $\begin{array}{l}0.06-0.08 \\
0.06-0.08\end{array}$ & $\begin{array}{l}0.06-0.07 \\
0.02-0.06\end{array}$ & & Peak levels \\
\hline $\begin{array}{l}\text { I966 } \\
\text { January }\end{array}$ & $0.02-0.03$ & - & $0 \cdot 1-0 \cdot 2$ & Nil detected & Nil detected & \\
\hline
\end{tabular}

closed for two weeks during the summer holiday period in January 1966, and a considerably improved ventilation system, including lip exhausts over the centrifuges, was brought into operation in December 1965.

Air testing was carried out when it was apparent from the urinary levels that there was a considerable hazard. The first survey in July 1965 was carried out by chemical analysis using acid permanganate solution as the absorption medium followed by dithizone analysis as outlined above. In successive surveys, analysis was performed by an ultraviolet absorption Beckman K.23 mercury vapour meter. The results are shown in Table II, and a line has been drawn across the table as the results from the first survey represent an average over the sampling period whereas the other results represent peak readings.

The results show that in the mould room, until the new exhaust system came into operation, the general air levels and the level in the air above the centrifuges considerably exceeded the recommended maximum level of $0.1 \mathrm{mg} . / \mathrm{m}^{3}$ and that the chief point of evolution was above the centrifuges. The exhaust system installed just before the December test, and which was being adjusted at the time of that test, brought down the general level well below the recommended maximum. In the oven room, levels were at or below $0.1 \mathrm{mg} . / \mathrm{m} .{ }^{3}$ except when the still was being emptied, although there was a disappointing rise in January 1966, the reason for which is not clear.

Although the numbers involved are small, there is no direct correlation between the air levels and urinary levels in the month of the test or the month following.

As a result of the investigations the following measures were recommended and have been carried out:

(a) Removal of all unnecessary apparatus and material from under tables, etc., which would hinder thorough, regular cleaning of the factory

(b) Removal of all mercury droplets and mercurycontaining dross into covered containers.

Recommendations $(a)$ and $(b)$ were brought into immediate effect between the July and November tests.

(c) Installation of an adequate forced exhaust system, incorporating efficient lip exhaust over the casting centrifuges in the mould room; this was installed in December.

It must be emphasized that at no stage did any of the employees show any overt signs or symptoms of mercurialism. In April 1965 all were referred for medical examination to their general practitioners, who were given a written guide regarding special points to be watched, such as tremor and personality change. Subsequently sickness absence was minor and followed a normal pattern. During the period of investigation only one of the workers (A) attended her general practitioner-for treatment for unrelated symptoms.

The levels of cadmium were also investigated at the beginning of the survey. No cadmium was detected in the air in the mould room (limit of detection $0.0 \mathrm{I} \mathrm{mg.} / \mathrm{m}^{3}$ ) but $\mathrm{r} \cdot 04 \mathrm{mg} . / \mathrm{m}^{3}$ was found in the oven room during emptying of the dross boxes. The operator wore a respirator for this operation. Urinary levels did not exceed $24 \mu \mathrm{g}$./1., less than a quarter of the maximum recommended level. Chest radiographs were normal. Tests for albumin by the heat/acetic acid method were negative in all specimens tested for mercury, and no Bence-Jones type protein was found in the speci- 
mens tested for cadmium when tested by controlled heating (Varley, 1958).

\section{Discussion}

Essentially, this investigation, apart from describing an unusual mercury hazard, serves to add to the evidence already published in the literature. It confirms that high urinary levels are not incompatible with good health (Moskowitz, I950; Friberg, I95I) and that urinary levels fall only slowly after cessation of exposure (Benning, 1958). The correlation between air levels and urine levels found by some investigators (Moskowitz, 1950; Elkins, 1959) was not apparent, possibly due to the small size of our survey. In short, this investigation does nothing to resolve the confusion that surrounds the whole subject of inorganic mercury exposure and its control by biological surveillance.

The fact that there is such apparently contradictory evidence may well mean that we are looking too closely for an arithmetical relationship between exposure and excretion without taking into account biological mechanisms. In the early investigations of the United States Public Health Service (Neal et al., 1937), it was stated that 19 of 33 cases of mercurialism showed no mercury in the urine: this might have been due to analytical difficulties or to the urines being heavily contaminated by bacteria. A second survey (Neal et al., I94I) showed that 30\% of mercurialism cases had no mercury in the urine. Bidstrup, Bonnell; Harvey, and Locket (I95I) mention that $300 \mu \mathrm{g}$./1. is frequently associated with symptoms of mercurialism; Jacobs and his colleagues (1964) studied 16 workers with mercurialism and found that the highest urinary mercury level was $600 \mu \mathrm{g}$./1., while II of the I6 had less than $300 \mu \mathrm{g}$./litre. Indeed, the evidence appears to be growing that possibly the majority of clinical cases have a lower level of urinary mercury excretion than might be expected from the air concentrations to which they are exposed and the urinary levels found in non-affected workers. It therefore seems possible that mercurialism might be due to an inability to excrete absorbed mercury rather than simply to exposure. This might be due to failure of the mercury to reach the kidney or to selective tubular resorption.

This hypothesis has marked implications on surveillance. The relationship of excretion to exposure proposed by Moskowitz (1950), Elkins (1959), and Kleinfeld, Messite, Kooyman, and Goldwater (196I) might well be valid even though this was not apparent in our small survey. Other authors (Bidstrup et al., I95I) have also failed to find a cor- relation but this may be due to a percentage of poor excretors in their samples: in other words, the more cases of mercurialism in the survey, the less correlation with exposure will be found. If the relationship is established in a series of unaffected groups, it seems that a theoretical 'norm' for the degree of exposure could be calculated for a particular working group. In the absence of evidence of lowered exposure, it would be men with urinary mercury levels below this 'norm' who should be more closely watched for early signs of mercurialism. The success of such a method would depend on the accurate estimation of the 'norm'. The development of a personal sampling device would be a valuable aid to research and may help to resolve some of the problems in this field.

Industry in New Zealand is not so highly developed that we can pursue this line of research, as the number of exposed workers is small. We hope, however, that this paper may suggest some lines of approach to those interested in this field and more fortunately placed.

Our thanks are due to Dr. E. R. Dowden, former Medical Officer of Health, Wellington, and Mr. G. Milne, Supervising Inspector of Health, Wellington, for their cooperation and assistance in this investigation; and to Miss S. A. Nicholls for analytical assistance.

We are grateful to the Director General of Health, New Zealand, for permission to publish this paper.

\section{REFERENCES}

Benning, D. (1958). Industr. Med. Surg., 27, 354.

Bidstrup, P. L., Bonnell, J. A., Harvey, D. G., and Locket, S. (I95I). Lancet, 2, 856.

Elkins, H. B. (1959). The Chemistry of Industrial Toxicology, and ed. John Wiley, New York.

Friberg, L. (I95I). Nord. hyg. T., 32, 240.

Goldwater, L. J., Jacobs, M. B., and Ladd, A. C. (I962). Arch. environm. Hlth, 5, 537.

$\longrightarrow,-$, and - (1963). Ibid., 7, 568.

-

Jacobs, M. B., Ladd, A. C., and Goldwater, L. J. (1963). Ibid., 6, 634 .

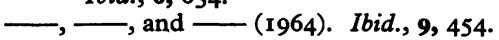

Kleinfeld, M., Messite, J., Kooyman, O., and Goldwater, L. J. (I96I). Ibid., 3, 676.

Ladd, A. C., Goldwater, L. J., and Jacobs, M. B. (1963). Ibid., 6, 480.

Magos, L., Tuffery, A. A., and Clarkson, T. W. (I964). Brit. F. industr. Med., 21, 294.

Moskowitz, S. (1950). Mth. Rev. Div. industr. Hyg., N.Y., 29, 20.

Neal, P. A. et al. (1937). Pub. Hlth Bull., No. 234, U.S. Govt. Printing Office, Washington.

- et al. (I94I). Publ. Hlth Bull. No. 263, U.S. Govt. Printing Office, Washington.

Varley, H. (1958). Practical Clinical Biochemistry, 2nd ed. Wm Heinemann, London. 